\title{
Abdullah Yusuf Ali's Methodology of Interpretation ( Linguistic Tafsir The Holy Of Qur'an )
}

\author{
$1^{\text {st }}$ Ulfah Nur Azizah ${ }^{1}, 2^{\text {nd }}$ Tety Juwariyah ${ }^{2}$ \\ \{ulfahnurazizah24@gmail.com ${ }^{1}$, tettyjuwairiyah@gmail.com $\left.{ }^{2}\right\}$ \\ UIN Syarif Hidayatullah Jakarta ${ }^{1,2}$
}

\begin{abstract}
This paper reveals the methodology of interpretation of Abdullah Yusuf Ali in his work The Holy Qur'an: Text Translation and Commentary. To obtain a broader understanding of interpretation, the author uses a synchronic linguistic approach in its presentation. His work The Holy Qur'an is quite famous in the Muslim world because of the different interpretations he uses. Usually the commentators use Arabic in interpreting the Qur'an, but Abdullah Yusuf Ali uses English so that it is easier for Westerners to study the Qur'an. In addition, he writes touch and interpretation in a poetic style at expressing a wider meaning and beauty. He tries to translate and interpret the verse with a socio-spiritual experience in which in his vision there are various perspectives, including the mistakes of human perspective to the spiritual world.
\end{abstract}

Keywords: Touched by the Qur'an, Abdullah Yusuf Ali, Poetry, Methodology of Interpretation

\section{Introduction}

As a book that provides guidance, the existence of the translation of the Qur'an is expected to help people from various countries in understanding its contents. In its history, the translation of the Qur'an had experienced a deadlock because it did not receive a warm welcome from the Muslims themselves. However, not a few scholars have finally allowed the translation of the Qur'an with very strict provisions, despite the debate, the translation of the Qur'an continues to this day.

The development of an interpretation of the Qur'an in another country or region is clearly different from what happened in the Arab world (the Middle East) where the Qur'an was revealed itself, the difference is mainly due to differences in cultural and linguistic backgrounds.

One of the translators of the Qur'an as well as the Indian Mufasir Abdullah Yusuf Ali with his expertise seen in translating and interpreting the Qur'an in his work The Holy Qur'an Text Translation and Commentary, his most famous work has made his name known in the Muslim world.

It is touched and interpreted differently because it is written in a poetic style, in his work Yusuf Ali translates into English as a form of expressing meaning and expanding from its Arabic meaning, he tries to translate and interpret the verse with socio-spiritual experience, which in his vision there are various perspectives, including the errors of human perspective to the spiritual world. As Yusuf 
Ali's interpretation with his Sufistic style, he places more emphasis on reason in order to gain wisdom. According to him, reason can be wrong and deviate from the truth, so we must be careful and more vigilant so that it is always in line with sharia and religious teachings[1].

\section{Methodology}

This study is included in the category of library research, using primary and secondary data obtained from the existing literature related to the theme raised. The primary data is with (The Holly Qur'an) Abdullah Yusuf Ali, with several interpretations of other commentators, in order to gain a broader understanding of the views of both the Western and Nusantara Mufasirs.

\section{Result and Discussion}

\subsection{Background of The Holy Qur'an}

Yusuf Ali, a commentator who came from India, participated in enlivening the treasures of Sufistic interpretation of the Qur'an by making translations and reviews of the Qur'an in English. His interpretation is known as an interpretation that is full of spiritual dimensions, he believes that there is an inner meaning behind the outer meaning of these verses. Nevertheless, he did not deny the physical meaning[2].

The research that has been carried out regarding Abdullah Yusuf Ali's interpretation is as stated in the journal written by M. Endy Saputro with the title "Alternative Trends in the Indonesian Qur'an, the book of Abdullah Yusuf Ali and Muhammad Asad's Tafsir that the book of interpretation of The Holy of Qur'an compares the translation of the Qur'an. -Quran in the English sense, in fact this is not easy because it requires an approach to the meaning of the verse with local words or meanings that do not necessarily have equivalent words, ${ }^{[4]}$ along with Zinia Maurisa, with the title of her thesis Criticism of Abdullah Yusuf Ali's method of commentary on the Qur'an (a critical study of the Qur'an, texts, translations, and commentaries, that Abdullah Yusuf Ali rarely uses history to analyze verses, Yusuf Ali did not want to emphasize the study only in certain events because the Qur'an not only came down to a country, but also applies to all times. Therefore, Abdullah Yusuf Ali carried out these rules from al ibroh bi al 'umūm al-lafdz lā bi al khuṣuss sabab[3].

Furthermore, research written by Fathurrahman with the title Semantic Analysis of Surat alKahf The Holly Qur'an by Abdullah Yusuf Ali. As in the results of Fathurrahman's research showing the semantic approach taken by Yusuf Ali that Surah Al-Kahf especially the story of Ashabul Kahf has information about the elements of lexical and grammatical meaning, here Fathurrahman only focuses on the translation of Surat al-Kahf in the translated semantic approach. Yusuf Ali.

Of all the works related to Abdullah Yusuf Ali's Interpretation Analysis (The Holy of Qur'an), the writer has not found any research that focuses on Yusuf Ali's interpretation in epistemology of Abdullah Yusuf Ali's interpretation/translation of the Qur'an in his work the Holy of Qur'an, because epistemology itself is a branch of philosophy that questions or investigates the origin, 
structure, method and truth of knowledge, so that with this it can be studied a basis or origin of the translation or interpretation of Yusuf Ali, namely the sources, methods and tendencies or pattern and validity of Yusuf Ali's interpretation. In addition, this article also wants to examine specifically the linguistic aspect of Yusuf Ali's interpretation/translation of the text of the Qur'an, especially on religious themes and Cosmological Verses because from several examples of his interpretation of these religious themes, Yusuf Ali often does ijtihad. linguistics so as to produce different meanings from other commentators.

This article aims to complement the shortcomings and provide a broader understanding of interpretation using a linguistic approach and explain how Abdullah Yusuf Ali's interpretation in interpreting religious verses and cosmological verses in particular, and seeing how Yusuf Ali's sufistic side interprets the Qur'an. Therefore, the author feels it is important to know the epistemology of Yusuf Ali's linguistic interpretation in the Holy Qur'an, as well as how Yusuf Ali interpreted religious verses and the cosmological and linguistic verses used by Yusuf Ali in interpreting the Qur'an. an[2].

\subsection{Biography of Abdullah Yusuf Ali}

Abdullah Yusuf Ali was born in Bombay a textile town in Gujarat, British India . His hometown became the residence of Bombay in the heyday of the Raj. He lived and grew up in the middle of the merchant family tajir. P utra Yusuf Ali Allahbuksh (died 1891), also known as Yusuf Ali Khan Bahadur, a Shi'a Isma'ili tradition Dawoodi Bohra, who left the traditional business community based work and instead became Superintendent of the Government. On retirement, he earned the title of Khan Bahadur for public service.

Abdullah Yusuf Ali was born on April 4, 1874. His mother died when he was a baby and he did not get to know his mother so that mother's love was separated from his consciousness. He also never mentions his mother while his father who raised and educated him is always remembered even when he wrote the introduction to his commentary, The Holy Qur'an, at the age of 62 years.

As a child Abdullah Yusuf Ali attended the Anjuman Himayatul Islam school and later studied at the Wilson College missionary school, both in Bombay. He also received a religious education and was eventually able to read the entire Qur'an by rote.He speaks Arabic and English fluently. He concentrated his efforts on the Qur'an and studied the interpretations of the Qur'an beginning with those written in the early days of Islamic history. He studied some English literature and visited several European countries as a student[4].

After young Yusuf Ali finished or completed his memorization of the Koran, his father gave Yusuf Ali a gift in the form of a feast so that he felt happy for an award given by his father and considered the importance of the Koran. Even at school Yusuf Ali received contemporary knowledge, besides that there was also a lesson that at the same time Arabic he never left or stopped studying the Koran.

Yusuf Ali is an intelligent student and has high achievements in academics, he has won a prestigious award, namely the Indian Civil Service Award. This award is a result of the highly competitive entrance examination in obtaining a high position in the Indian Civil Service. People who have high incomes or are considered middle to upper class in general really want their sons to get this award. 
Yusuf Ali is considered a person who easily understands English literature, and among other Indians he is considered the best person, of course in this case writing in English. Not only that, not even a few of his works were published in the most popular academic magazines in India. To the extent that the media praised Yusuf Ali's beautiful writing style.

After that, Yusuf Ali left India and headed for the plains of Europe. Many capitals there he visited, but in the end he chose London, England as the city where he lived for some time. While living in London, he read a lot of translated Koran. He continued to instill a high demand for the Qur'an and studies of the Qur'an. Then Yusuf Ali began to study the Koran carefully, and pay more attention to various interpretations of the Koran, both classical and contemporary.

After he learned some things written about the Koran in European and Eastern languages, Yusuf Ali immediately returned to India. Arriving in India, he chose a new place of residence, namely in Lahore, and there he became the Dean of the Islamic College. Then he just started his monumental work, namely translating and commenting on the Koran[5].

Yusuf Ali's life in public is different from his private life (Private Life). He is known to be flexible, his achievements are not only in the Arab region alone. He soon passed the autumn/winter of 1938 after his translation was published in both the UK and the US. He was someone who first opened a mosque in Canada, precisely in the city of Edmonton in December 1938 and was named al-Rashid Mosque.

He left an interesting impression with all that came in connection with his life failing miserably. His first wife proved unfaithful and married another man as well as the second wife, Gertrude Anne Mawbey or Mauma. From the couple Anne left an only son. He is Rashid who is far from his father. Abdullah Yusuf ali lived alone until one day the police found him lying in front of a Westminteer house on 09 December 1953. He was in a sad accident, confused, lost. Police took him to a local hospital and placed him in an old house on Dove House St, Chelsea. The next day the condition worsened. He died at St. Stephen's hospital December 10, 1953. He is buried in Bookwood Cemetery[6].

Eighty-one years of his life were spent in India and England a career in Indian and British government. Married twice to two British women and like his senior, Ahmad Khan, he defends the interests of Muslims with great loyalty. In his personal, social and even religious life, Abdullah Yusuf Ali tries to combine West and East, an idealism that is complicated and full of challenges he wants to embody in his personality and thoughts.

The figure of Abdullah Yusuf Ali is a popular figure among Indian Muslims and is seen as the most important representative of Muslims in British India's view. However, he did not gain commensurate popularity among Indian Muslim reformers, so his name was barely recorded in the Indian Islamic reforms. He made up for these shortcomings with an extraordinary reputation by creating works of interpretation of The Holy Qur'an which almost penetrated all corners of the Islamic world

In addition, Yusuf Ali is known as a writer who is very skilled in giving speeches and good at writing. Of the various works that have been published, his most phenomenal work is The Holy Qur'an: Text, Translation, And Commentary, a book of translations of the Qur'an accompanied by several of his interpretations. This work is the result of contemplation accompanied by rihlah .

Yusuf Ali is also very interested in something mysterious. He is very interested in discussing the symbols contained in the Qur'an. It has reference to people who have inner knowledge or 
mystical knowledge. Such sentiments are in accordance with the interpretation of the Qur'an as a guide for the development of each individual[7].

\subsection{The holy Qur'an}

Abdullah Yusuf Ali's life was full of stress. Where the emotional trauma due to the abuse committed by his wife, Teresa Shalders, in 1911 and the hostility of the children from the marriage in 1920, changed Abdullah Yusuf Ali's perception. His religious zeal was rekindled. Abdullah Yusuf Ali's bond with the Qur'an was formed during times of anger and stress while seeking consolation. The messages contained in the Qur'an became help and hope for Abdullah Yusuf Ali, ${ }^{[15]}$ Abdullah Yusuf Ali's stressful times are outlined in the preface to this commentary, and there are also in several places in his commentary, there are several descriptions of how the great inner turmoil that brought spiritual understanding that purified the soul, nourished the spiritual life, with According to the author, Yusuf Ali used the Qur'an as solace, comfort for the soul, and a remedy for the pressure he was suffering, so that it became one of the factors that Yusuf Ali interpreted the verses with spiritual meaning.

Judging from his interpretation, Yusuf Ali did not deny the physical meaning of the verses of the Qur'an. He justifies the physical sense, but he places a stronger emphasis on the spiritual meaning. According to him, God's words are not just physical statements. Allah also reveals spiritual realities (inner side of the verse) ${ }^{[16]}$ from this it can be seen that Yusuf Ali is not only concerned with the dzahir verses but tries to explore the inner meaning of the verse.

As when Yusuf Ali interpreted Surah al-Zumar verse 27:

And indeed, We have set forth in this Qur'an all kinds of parables for mankind so that they may learn (Surah al-Zumar [39]: 27)

According to him, humans can understand higher spiritual truths only with parables and figures of speech, all of these are abundant in the Qur'an whose purpose is not only to tell stories, but to teach spiritual wisdom[8].

Abdullah Yusuf Ali so unifies the rhythm of the music and the tone of his native language that so majestic and beautifully reflects on this translation, so that the reader can read it not only with the eyes, tongue and voice, but also with a light that fills the human intellect, even with the deepest and deepest light. which is given by conscience and the inner consciousness of man.

He also translated the Qur'an with a poetic commentary in quite a number of verses. He has reviewed the translation in the form of a numeralization of 300 reviews in the form of poetry[8].

The Holy Qur'an: Text, Translation and Commentary is the result of reflection from his thoughts which of course is also influenced by many factors, such as the level of intelligence, psychological condition of the author, personal tendencies, the interests of a group, educational background, even the development of science, and social conditions. society at that time. All of these are influenced much on the results of his thinking. With so would saw the advantages and shortcomings in presenting its interpretation

The events experienced by Abdullah Yusuf Ali when he found the Qur'an in times of suffering[6] it is not only stated directly in the preface to The Holy Qur'an, but also in several places in its commentary. There is a picture of how many great inner turmoils turn out to be good news of 
the coming spiritual understanding that purifies the soul and nourishes the spiritual life that was previously barren like a desert. For him, religion became the main concern of personal piety.

The whole phenomenal world is a symbol, while the reality is behind it, it encourages Abdullah Yusuf Ali to continue to look for symbols in the verses of the Qur'an. For example, the fish is a symbol for secular knowledge, the sun is a mystical reference, for reason and salt is a symbol for the most hidden mysteries. There are many explanations regarding the Qur'anic reference to water and light and abbreviated letters or muqatta'at[9].

The Holy Qur'an: Text, Translation and Commentary which is the subject of discussion in this paper consists of:

The first edition of the foreword was written by Abdullah Yusuf Ali on April 4, 1934 AD to coincide with the 18th Dzulhijjah $1352 \mathrm{H}$. in Lahore. This foreword contains an explanation of the history of this translation project, its work plan, as well as the goals of Abdullah Yusuf Ali who cannot be separated from the outpouring of his heart.

Abdullah Yusuf Ali provides an English translation side by side with the Arabic text. Abdullah Yusuf Ali put so much effort into the rhythm of the music and the tones of his native language that are so sublime and beautiful reflected in this translation, so that the reader can read it not only with the eyes, tongue and voice, but also with a light that fills the human intellect, even with the deepest and deepest light. which is given by conscience and the inner consciousness of man. It is natural that this work is very monumental, because Abdullah Yusuf Ali has traveled, rihlah ilmiyah, made notes, met figures and explored their minds and hearts to complete this task. For more than forty years this ideal was raging in his mind[10].

The Arabic text printed with the Ottoman rasm looks different in the opposite line. Each sura and verse is assigned its own number on each page. The verse numbering system is mostly according to the Egyptian edition.

The system of using the number 'ayn is used as is generally used in Arabic texts with the title Section. Another Tool for showing the section number of each ayn with a capital letter beginning in bold. While notes have an important role in this translation. Regarding the main questions, explanations are obtained in the notes. If he abandons the literal translation, it is meant to emphasize the spirit of the original which is better in English as this is explained in the notes.

The summary is numbered sequentially ( running commentary) from one to three hundred, beginning with the introduction and ending with the conclusion. This summary is compiled in an unrhymed rhyme style. Footnotes start at number one in summary 19 on page 5, not start from the Arabic text up to 6311 in summary conclusions on page 1811 .

When the sura is long, the subject matter is preceded by a summary of the interpretation in a short paragraph that is adjusted to the place of certain verses. Summary letters are printed smaller than the English text. Each sura is given a number, followed by the number of verses from the sura in question, while the name of the sura is given in Arabic on the right side which between the two is the number that indicates the page.

Furthermore, each surah also begins with a brief introduction about the content of the surah to be discussed, as is the case with the general surah in the translation of the Qur'an or interpretation. The Holy Qur'an: Text, Translation and Commentary does not always have a conclusion. As an example, you can see the introduction to surah al-Baqarah and its closing with appendix 1, but at the end of surah Âli Imrân there is no appendix. This is because it depends on the needs of the surah in question on the explanation in the related appendix[11]. 
Such a wide translation required him to refer to several reference books. Abdullah Yusuf Ali divides these reference books into two categories, the first category, consisting of (1) previous books, (2) existing translations, and (3) dictionaries and general reference books that are easy obtained.

The second category, is the details of the third part in the first category, namely: (1) al- Mufradât by Abû al-Qâsim al-Husaynî Râghib al-Isfahânî, an Arabic dictionary of words and phrases in the Qur'an. an, (2) Qamus, a well-known Arabic dictionary, (3) Lisân al-Arab, also a well-known Arabic dictionary, (4) Sûrah, an Arabic-Persian dictionary, (5) Dictionary and Glossary of the Newspaper by J. Penrice, (6) English-Arabic Lexicom by EW Lane, (7) al-Itqân fî 'Ulûm al-Qur'ân by Jalal al-Dîn al-Sayût\}î, an encyclopedia of the Qur'an which very broad, (8) Geschichte des Qorans by Noldeke Und Schwally, German essay on the chronology of the Qur'an whose criticisms and conclusions are from the point of view of non-Muslims, (9) Encyclopedia of Islam, (10) Encyclipedia Britanica, fourteenth edition, to which the knowledge of the Arab world is based, (11) Dictionary of Islam by Hughes, an outdated but still useful as a reference, (12) Sirat al-Rasl by Ibn Hisham about the history of the apostle in detail, (13) Sirat al-Nabi by Maulana Syibli Nu'mânî (d.1914 AD/1334 H) a history of the life of the Prophet in Urdu , (14) Fath al- Rahmân by Faidullah Bek Hasani, a 1346 Cairo concordance of the Qur'an in Arabic[12].

According to Abdullah Yusuf Ali, in this world there is no book whose handling requires so much expertise, requires so much energy, time and money as people do with the Qur'an.

In translating, each translator is expected to understand as closely as possible the original translated text. Every sincere translator has the right to use his knowledge and experience to understand the Qur'an. However, sometimes in translating texts there are still some difficulties, including:

- Arabic words in the Qur'an have different meanings than those understood by the Prophet. This is understandable because all languages undergo a transformation in connection with the development of the speakers of the language concerned.

- In connection with the development of the transformation of the Arabic language, many later commentators abandoned the previous interpretations without any clear reason.

- Each root of classical Arabic vocabulary is so broad that it is very difficult to obtain vocabulary diction in translation into modern language analytically word for word or using the same word as the original language in the Qur'anic texts.

- Every time there is an error or contradiction in certain material in the Qur'an's rich vocabulary which distinguishes between the meaning of certain things and ideas with specific words, which are also common words in English.

- God's purpose is eternal and His plan is perfect, while human reason is limited to the best possible level. In the person of the same person the intellect may grow or decline depending on the strength or breadth of his experience. $\stackrel{[26]}{ }$

Approach Used by Abdullah Yusuf Ali in Translating the Qur'an Abdullah Yusuf Ali has translated the Qur'an from Arabic as the source language into English as the target language. He translates according to the touch, that is, interpreting vocabulary lexically by not denying grammatical, contextual and socio-cultural understandings, so that it is free from the prohibition or prohibition of being literally touched by vocabulary. 
Abdullah Yusuf Ali translated the Qur'an with a poetic commentary in quite a number of verses. He has reviewed the translation in numerical form as many as 300 comments in the form of poetry, this review is made on every verse that is deemed necessary. For example, surah Yasin which consists of 83 verses, starting from the introduction to sura xxxvi (Yasin) on page 1168 to page $1188[13]$.

For a long time he has been studying the Qur'an and about the intricacies of its classical and upto-date interpretations written in both Western and Eastern languages. All of this was absorbed very well. Abdullah Yusuf Ali is also known as an enthusiast of literature, especially Persian and Classical English literature. He was well acquainted with the Shakespeares and the poems of Milton, Wordsworth, Shelley, Tennyson, Keats and others[7].

\subsection{Abdullah Yusuf Ali’s Methodology of Interpretation}

The study of interpretation using a linguistic approach has been developed by several contemporary interpreters, including Abdullah Yusuf Ali. In interpreting/translating verses of the Qur'an, Yusuf Ali cannot be separated from the linguistic ijtihad he uses, Yusuf Ali makes semantics ${ }^{[30]}$ as the basic principle or device of his approach in understanding the text of the Qur'an.

Yusuf Ali's perspective and method of linguistic ijtihad tends to use the semantic awareness approach of basic meaning (lexical semantics/al-ma'na al-asāsī) or descriptive semantics (synchronic linguistics). This was done by Yusuf Ali because by using a lexical semantic approach (al-ma'na al-asāsi), the meaning of the Qur'an can be known which is almost the same as during the revelation period, but he interpreted vocabulary lexically without denying grammatical meanings, contextual and socio-cultural conditions, so that apart from the prohibition or prohibition of being touched literally vocabulary.

Regarding the translation of the text of the Qur'an, especially religious themes, which says that the translation or interpretation of the verses of the Qur'an must be as close as possible to the meaning that was understood at the time of its descent or at the time of the Prophet Muhammad, it is in line with the theory of descriptive semantics or synchronic linguistics, for example. the term alIslam, according to Yusuf Ali the term refers to an inclusive meaning or a generic meaning not specifically $\stackrel{[31]}{ }$ as in the letter li 'Imrān verse 19:

Verily, the religion with Allah is Islam. There is no difference between those who have been given the Book except after they have acquired knowledge, because of envy between them. Whoever disobeys the signs of Allah, then indeed, Allah is swift in reckoning.

Here, Yusuf Ali interprets it more to value (one's submission to God) not to religion which has a formal meaning. therefore, if one seeks a religion other than submission to God, it will not be accepted by him.

Similar to the term "al-Islam" above, Yusuf Ali interprets the word "muslimūn" according to its generic meaning. That is "those who surrender to God". ${ }^{[32]}$ His interpretation is in Ali Imran verse 84 .

Say (Muhammad), "We believe in Allah and in what was revealed to us and revealed to Abraham, Ishmael, Isaac, Jacob and their descendants, and what was given to Moses, Jesus and the prophets from their Lord. We make no distinction between any of them and to Him we submit." 
It is clear here that Yusuf Ali does not interpret the term Islam as a particular religious institution "Islamic religion" but a meaning that has a more general scope and does not formally refer to a particular religion. The understanding of al-Islam that Yusuf Ali wants here is more of a semantic awareness whose study or understanding is based on the basic meaning (lexical semantics/dilälah al-Fadh)[14].

In another interpretation he emphasizes his inner meaning "exoteric hermeneutics", and using several terms for the symbolic language of the Qur'an, such as metaphor ( metaphor), allegory ( allegory), in addition to symbol ( symbol) and figurative meaning (figurative meaning, figurative word ). that the meaning intended by a word is not the literal meaning, but another meaning behind it.

As in Surah al-Zumar verse 27 he translates as follows:

Humans can understand higher spiritual truths only with parables and figure of speech and all of these are abundant in the Qur'an whose purpose is not only to tell stories, but to teach spiritual wisdom.

Yusuf Ali in interpreting symbolically on the meaning of God, namely the light above in a cosmological perspective, such as demons, jinn and angels, against the word spirit and soul, Yusuf Ali interprets the spirit with the meaning of spirit.

In this verse, according to Yusuf Ali, another meaning behind the literal understanding is spiritual qualities or spiritual truths, or high realities, the analogy of heaven and earth, there is a need for spiritual truths that have links from high truths to truths that are true. lower than God's creation, as for the highest realities such as heaven and hell, reward and sin, the hereafter and justice, all of which may be understood with metaphorical expressions, namely in the form of parables[6].

\subsection{Characteristics and Patterns of Interpretation}

The Holy Qur'an, by Abdullah Yusuf Ali, has different characteristics from the interpretations in general as it is known to be written in Arabic, while this commentary is written in English and has certain characteristics, namely[15].

1. The beginning is written with an introduction, body, and closing. Furthermore, the interpretation ends with an analytical index that functions as a helper in finding a kind of short cut of the themes that you want to study

2. Topics listed at the beginning; interpretation of the Koran, translations, and reference books (history of translation development)

3. Give views or criticisms of previous works

4. The book of portable commentaries which is the characteristic that is highlighted

5. Provide commentary notes; made densely at the bottom and try to make the comments relevant to the things discussed

6. More of the focus discussed is on spiritual matters

7. Avoiding theological debate

8. Revealing asbabun nuzul to help understand the text

The style of interpretation in The Holy Qur'an is spiritual or Sufistic. His spiritual interpretations focus a lot on the symbols revealed in the Koran. He assumes that the verses in the Koran are signs given by God, thus making him interested in the various symbols in the Koran and doing ta'wil on these symbols as well as emphasizing their inner meaning[16]. 
There are several terms used by Yusuf Ali in translating the Qur'an to refer to the symbolic language of the Qur'an, such as metaphor (metaphor), allegory (allegory), in addition to symbols and figurative meanings (figurative meaning, figurative word). All the terms used contain the meaning that what is meant by a word is not the actual literal meaning, but that there is another meaning or meaning behind it.

As an example of the analogy of heaven and earth, from one perspective it can be said that the other meaning behind the literal meaning is spiritual qualities, spiritual truths, or high realities. This means that there is a need for spiritual truths that are relative from the highest truth to the lowest and crudest of His creation[17].

\subsection{Strengths and Disadvantages of Tafsir The Holy Qur'an}

If you look at the work of Yusuf Ali, which has become a reference in various countries, it can be said that it has contributed, especially in Islamic studies and Tafsir, where this interpretation is in accordance with the rules, especially in the field of linguistics with a beautiful language style in the form of poetry. interpretation using the English language which can make it easier for readers, especially Westerners, to get to know Islam[18].

However, if you look at the shortcomings in this interpretation, it is a short explanation and it is unfortunate that he only explains words or meanings that are difficult to understand, his interpretation which has drawn a lot of controversy does not change Yusuf Ali's spirit in working and pouring his thoughts into the book of interpretation of the Holy Qur'an. 'an who has made his name fragrant.

\section{Conclussion}

Thus a brief review of the interpretation of The Holy Qur'an: Text, Translation, And Commentary seen in Yusuf Ali's interpretation in his work The Holy of Qur'an, he places more emphasis on the language aspect and interprets the verse spiritually (sufistically/spiritually) by using the synchronic or semantic linguistic approach of the basic meaning that can be seen in the meaning of Islam, as well as emphasizing the inner meaning that can be seen in the cosmological verse, it emphasizes language style by using rhythmic poetry to make it easier for readers to understand the tarsir.

Especially in religious themes, Yusuf Ali is more general in the meaning of Islam, because his focus is on interpretation into English and looks more at the language aspect, and Yusuf Ali intendebecause he wanted to give a more moderate view, Yusuf Ali has contributed his thoughts and work in this study. Islam, especially in the field of interpretation to introduce Islam among the West. 


\section{References}

[1] N. Baidan, development Tafsir al-Qur'an in Indonesia. 2003.

[2] S. Ibrahim, "A Study of The Holy Qur'an by Abdullah Yusuf Ali," Hunafa J., vol. 7, no. 1, 2010.

[3] M. N. Fatimah, "Sufistic Dimensions in The Holy Qur'an Translation and Commentary,"

Postgraduate IIQ Jakarta, 2017.

[4] M. E. Saputro, "Alternative Trends in the Indonesian Qur'an," Postgrad. Gadjah Mada Univ. AlTahrir, vol. 11, 2011.

[5] Z. Maurisa, Criticism of Abdullah Yusuf Ali's method of commentary on the Qur'an (critical study of the Qur'an, text, translation, and commentary). Walisongo, 2010.

[6] Fathurrahman, "Semantic Analysis of Surat al-Kahf's The Holly Qur'an by Abdullah Yusuf Ali," Gorontalo: State University, 2015.

[7] A. Y. Khizar Humayun Ansari, Ali, Oxford Dictionary of National Biography. Oxford University Press, 2012.

[8] A. Ahmed and S. Fatima, "The Holy Quran: Text, Translation and Commentary by Abdullah Yusuf Ali (a Critical Review)," Holy Quran Text, Transl. Comment. by Abdullah Yusuf Ali (a Crit. Rev., vol. 1. [9] Y. Ali, The Holy Quran: Text, Translation, and Commentary. Lahore: Ashraf Press, 1972.

[10] H. Maulana, The Holy Qur'an: Text, Translation And Commentary. Sunan Kalijaga State Islamic University Yogyakarta, 2008.

[11] "The life story of Abdullah Yusuf Ali brought about many events that made him experience many changes. The emotional trauma caused by the betrayal of his wife, Teresa Shalders, in 1911 and the hostility of the children from his marriage in 1920 have change."

[12] "Abdullah Yusuf Ali's expertise in translating and reviewing the Qur'an is his most famous work. The Holy Qur'an: Text, Translation and Commentary has made his name known in the Muslim world. Translations, reviews, appendices and commentaries written in an."

[13] Mulyadi, "Islamic Concepts in the Qur'an, Textual and Contextual Studies," J. Islam. Stud., vol. 5. [14] "Noreview made and divided from paragraphs 1 to 32 on the starting page in the review letter no. 194. The next commentary is made in the same surah that is made from verses 33 to 50 in commentary number 195 on page 1177 . The next commentary from paragraph ."

[15] "Semantics according to Alfred Korzybski, is a branch of general linguistics. General linguistics is a general concept given to basic theories, basic concepts, models and methods of language investigation. symbol or study of meaning. See Harimurti Kridalak."

[16] S. Al-Khalidy, Stories from the Qur'an Lessons from the Ancients. Jakarta: Gema Insani Press, 2000. [17] M. U. Khusnan, "Esoteric Interpretation An 'Forgotten' Model of 'Elite' Interpretation," Suhuf J., vol. 3, no. 1, 2010.

[18] A. Y. Ali, Preface to First Edition. Maryland: Amana Corpuration, 1989. 